\title{
BOARD COMPOSITION, BOARD SizE AND FinANCIAL PERFormance of Johannesburg Stock EXchange Companies
}

\author{
Munyradadzi Raymond Muchemwa and Nirupa Padia \\ School of Accountancy, University of the Witwatersrand \\ Chris William Callaghan \\ School of Economic and Business Sciences, University of the Witwatersrand \\ Accepted: June 2016
}

\begin{abstract}
On the basis of agency theory and resource dependence theory, as well as other corporate governance literature, it is predicted that board composition measured as the ratio of non-executive to executive board members and the number of directors on a firm's board can be positively related to firm performance. This study seeks to test the predictions of this body of theory and to investigate the form of the empirical relationships among these effects. In so doing, this study tests theory that relates these variables in the context of a developing country, using data from South Africa's Johannesburg Stock Exchange, over a seven-year period, 2006-2012.
\end{abstract}

Key words: board composition, corporate governance, accounting, auditing

JEL: M400

\section{$1 \quad$ Introduction}

The high-profile corporate failure of companies such as Enron and WorldCom (Rashid, 2011) internationally, and LeisureNet, Regal Treasury Bank Limited and Saambou Limited in South Africa (Sanda, Garba \& Mikailu, 2011), has attracted both academic and commercial interest (Rossouw, 2005). There is now general agreement that when companies are well governed superior performance is promoted (Kyereboah-Coleman \& Biekpe, 2005). However, despite this general agreement, two areas of tension in the governance literature remain unclear, namely the relationship between firm performance and board composition and the relationship between firm performance and board size.

With reference to board composition (in terms of the ratio of non-executive to executive directors), some studies (Weisbach, 1988; Pearce \& Zahra, 1992; Daily \& Dalton, 1993; Rosenstein \& Wyatt, 1994; MacAvoy \& Millstein, 1999; Krivogorsky, 2006) suggest a positive relationship between board composition and firm performance, while others have found no such relationship (Bhagat \& Black, 1999; Daily \& Johnson, 1997; Dulewicz \& Herbert, 2004), or argue that empirical findings suggest that reducing insider directors can harm firm performance by depriving boards of valuable firm and industry-specific knowledge (Finegold, Benson \& Hecht, 2007).

Similarly, there is obvious disagreement between the literature that argues that board size can be positively associated with firm performance and that which contests this. Some theorists maintain that there are a host of advantages to larger boards ( $\mathrm{Wu}, 2003)$, as greater numbers of people are able to monitor management actions (Nicholson \& Kiel, 2003), allowing for better management of the agency problem. Moreover, in some contexts the argument in favour of larger boards has found empirical support (Mak \& Li, 2001). However, other literature on board size has contested this and has argued for smaller boards (Wu, 2003) because of advantages related to cohesiveness and higher productivity, as well as their ability to monitor the firm more effectively than larger groups (Pablo, Valentin \& Felix, 2005). Smaller boards are less likely to participate in social loafing and have lower coordination costs, but makes them less effective in monitoring (Rashid, 2011). 
Given this relative lack of clarity, particularly in relation to the South African context, this study investigates the relationships between measures of firm performance and these two dimensions of corporate governance, namely board composition and board size. Measures of firm performance in this study include Tobin's $Q$ (TOB), return on assets (ROA) and return on equity (RO) and are applied to firms listed on the Johannesburg Stock Exchange (JSE). Data across the years 2006 to 2012 is used to test the theory that predicts relationships between these dimensions and firm performance.

This study therefore seeks to investigate whether board composition, specifically in terms of executive versus independent non-executive directors, is associated with firm performance, and also whether board size is associated with differences in firm performance in the South African context. The paper proceeds as follows. First, theory is discussed and hypotheses derived. Next, the methodology applied in the research is considered. Empirical results are then reported. The paper concludes with a discussion of the results and recommendations for further research are derived.

\section{Conceptual scope}

Two bodies of theory dominate the literature that relates board composition and board size to the performance of firms, namely, agency theory and resource dependence theory. These theoretical frameworks are considered as follows.

\subsection{Agency theory}

Monitoring the functioning of boards, or the 'control' role (Boyd, 1990; Johnson, Daily, \& Ellastrand, 1996), is an important focus of corporate governance research (Hillman \& Dalziel, 2003). The primary theoretical framework that relates this monitoring function to firm performance is derived from agency theory, which predicts that conflicts of interest can arise from the separation of ownership and control in organisations (Berle \& Means, 1932; Fama \& Jensen, 1983). From this perspective, the primary function of boards is to monitor the actions of managers (agents) in order to protect the interests of shareholders (principals) (Mizruchi, 1983; Eisenhardt, 1989; Andreasson, 2011). Should management pursue their own interests at the expense of the shareholders' interests (Nicholson \& Kiel, 2007), 'agency' costs typically arise (Berle \& Means, 1932). Monitoring by boards of directors may therefore reduce the agency costs inherent in the separation of ownership and control and, in this way, improve firm performance (Fama, 1980; Zahra \& Pearce, 1989). Agency theory also predicts that the incentives available to directors and boards vary and are therefore an important precursor to effective monitoring (Kyereboah-Coleman \& Biekpe, 2005), and that firm performance will therefore improve if these are aligned with the interests of shareholders (Jensen \& Meckling, 1976; Fama, 1980).

\subsection{Resource dependence theory}

Another important function of a board is the provision of resources (Nicholson \& Kiel, 2007). This perspective represents the dominant perspective in the literature (see Pfeffer, 1972; Pfeffer \& Salancik, 1978; Boyd, 1990; Daily \& Dalton, 1994; Gales \& Kesner, 1994; Hillman, Cannella, \& Paetzold, 2000) relating to the resource dependence (Hillman \& Dalziel, 2003) and stakeholder traditions (Johnson \& Greening, 1999; Luoma \& Goodstein, 1999; Hillman, Keim \& Luce, 2001).

The theoretical underpinning of this body of literature rests on Pfeffer and Salancik's (1978) work on resource dependency. Pfeffer and Salancik (1978:163) note that "when an organisation appoints an individual to a board, it expects the individual will come to support the organisation, will concern himself with its problems, will invariably present it to others, and will try to aid the organisation". Boards may therefore offer the following four primary benefits: (i) advice and counsel, (ii) legitimacy, (iii) channels for communicating information between external organisations and the firm, and (iv) preferential access to commitments or support from important elements outside the firm (Pfeffer \& Salancik, 1978). Resource dependence logic therefore 
suggests that a board's provision of resources is directly related to firm performance (Nicholson \& Kiel, 2007). Resources help reduce the dependency between the organisation and external contingencies (Pfeffer \& Salancik, 1978), diminish uncertainty for the firm (Pfeffer, 1972), lower transaction costs (Williamson, 1984), and ultimately aid in the survival of the firm (Singh, House \& Tucker, 1986).

Having considered the theoretical framework that predicts relationships between company performance and board composition and size, the empirical literature relating to these relationships is now reviewed and hypotheses are derived for testing.

\section{Board composition and company performance}

Board composition can reflect various degrees of heterogeneity (Bhagat \& Black, 2002). Common measures of board composition include the ratio of independent non-executive directors and board size (Rashid, 2011), which is the measure used in this research. Other measures of board composition in the literature include gender and age diversity. However, to date there have been inconclusive findings as regards the relationship between board composition and firm performance (Finegold et al., 2007; Bermig \& Frick, 2010; Rashid, De Zoysa, Lodh \& Rudkin, 2010). Other differences in board composition are considered here to represent 'board diversity'. More independent board composition can result in enhanced decision making through increased information flows, although this may entail a cost (Sanda et al., 2011). In light of this, Eklund, Palmberg and Wiberg (2009:8) stress board heterogeneity entails a trade-off between "information efficiency" in the case of heterogeneous boards, which typically are better informed on 'outside' issues, versus "decision efficiency" of homogenous boards deriving from higher trust, shared experience and values.

In terms of this tension, however, agency theory is in favour of a majority of independent nonexecutive directors (Huse, 2007; Rashid, 2011). King III stresses that the board should include a balance of executive and non-executive directors, with a majority of independent non-executive directors, as this reduces the possibility of conflicts of interest (IOD, 2009). The corporate governance literature tends to advocate expanding the independent/outsider elements on corporate boards (Sanda et al., 2011). Sahin, Basfirinci and Ozsalih (2011), however, observe that previous literature does not offer consistent evidence on the impact of the proportion of non-executive to executive directors on financial performance.

On the one hand, certain studies (Weisbach, 1988; Pearce \& Zahra, 1992; Daily \& Dalton, 1993; Rosenstein \& Wyatt, 1994; MacAvoy \& Millstein, 1999; Krivogorsky, 2006) suggest a positive relationship between board composition and firm performance. Others, on the other hand, have found no relationship between firm performance and board composition (Daily \& Johnson, 1997; Bhagat \& Black, 1999; Dulewicz \& Herbert, 2004).In support of the latter camp, Finegold et al. (2007:867) note that no consistent empirical evidence has been found to suggest increasing percentages of outsiders on boards will enhance performance, but "pushing too far to remove insider and affiliated directors may harm firm performance by depriving boards of the valuable firm and industry specific knowledge they provide."

An argument challenging the role of independent non-executive directors rests on the information asymmetry between executive directors and independent non-executive directors (Rashid, 2011). Executive directors are nested within the company they govern and may therefore have a better understanding of the business than independent non-executive directors and may, in addition, be better able to make useful decisions (Sanda et al., 2011). By contrast, independent non-executive directors may lack day-to-day inside knowledge of the company and therefore may play a reduced control role in the firm (Nicholson \& Kiel, 2007; Rashid et al, 2010). Nevertheless, this debate is set to continue, as there are no empirical findings to tilt the argument in any particular direction (Rashid, 2011).

There are several explanations for the inconclusive results on the relationship between executive versus independent non-executive directors and firm performance. One such explanation 
is that the simultaneity between key variables of interest confounds the interpretation of the results in studies that focus on direct relationships (Finegold et al., 2007). Yet another explanation is that performance and board characteristics are jointly endogenous, and thus firm performance is not only a function of past board independence, but also influences board structure (Panasian, Prevost \& Bhabra, 2008).

Nonetheless, Panasian et al. (2008:136) stress that, "despite the inconclusive results of empirical literature on the effectiveness of outsider directors on the board, an international movement advocating greater board independence continues to strengthen". Given the lack of clarity as regards the net effect of board composition and size on firm performance, this study seeks to address what is considered to be a deficiency in the literature, and to investigate the net relationships between board composition and firm performance in the South African context. On the basis of the theory and the empirical findings discussed above, the following hypothesis is offered:

$H_{1}$ : Board composition (the proportion of outside independent directors) is significantly and positively associated with firm performance.

The following section accordingly reviews the literature relating to the relationship between board size and firm performance.

\section{Board size and firm performance}

A board of directors fulfils various functions (Solomon, 2010). While independent non-executive directors monitor the executive management and advise the CEO on business strategy, information is also conveyed to outsiders (Mace, 1971; Lipton \& Lorsch, 1992; Jensen, 1993). Much of the literature on board size has, however, argued for the benefits of smaller boards (Wu, 2003), based on the notion that smaller groups are more cohesive and more productive, and are also able to monitor the firm more effectively than larger groups (Pablo et al., 2005). Similarly, larger groups are fraught with problems such as social loafing and higher coordination costs, and are thus less effective in terms of monitoring (Rashid, 2011).

Lipton and Lorsch (1992) argue that boards comprising eight or nine members are the most effective. According to these authors, when the board exceeds this optimal size, it becomes difficult for all the board members to express their ideas and opinions in the limited time available at board meetings. Jensen (1993) concurs with this view and argues that boards of more than seven or eight members function less effectively and are easier for the CEO to control than smaller boards. Yermack (1996) provides empirical support for these arguments by showing a significant negative correlation between Tobin's $Q$ and board size for large public firms in the United States (US).

According to the body of literature that argues that board size is positively associated with firm performance, larger boards provide a host of advantages (Wu, 2003). From an agency perspective, it may be argued that a larger board is more likely to be vigilant with regard to agency problems simply because a greater number of people will be reviewing management actions (Nicholson \& Kiel, 2003). Accordingly, Mak and Li (2001) showed a significant and positive correlation between Tobin's $Q$ and board size for Singapore firms in OLS regressions. Nevertheless, agency theorists recognise that there is an upper limit to boards (Huse, 2007). Jensen (1993) suggests this limit to be approximately eight directors, as a greater number would interfere with group dynamics and inhibit the performance of the board. Alternatively, it may be argued that it is not the size of the board that is critical, but rather the number of independent non-executive members on the board (Dalton, Daily, Johnson \& Ellstrand, 1999). This study therefore tests both of these dimensions.

From a resource dependence theory perspective, it may be argued that a larger board offers greater opportunities for external linkages and hence access to resources (Nicholson \& Kiel, 2003). A host of studies (see Pfeffer \& Salancik, 1978; Klein, 1998; Hillman et al., 2000) argue that boards link a firm to its external environment; one of the functions of directors is to provide 
assistance in obtaining resources from outside the firm (Nicholson \& Kiel, 2003). Pfeffer (1972) suggests that the need for external resources such as debt finance would increase the CEO's need for advice and thus the size of the board of such a firm would probably increase. Booth and Deli (1999) found that firms that require more debt financing are more likely to have a commercial banker on the board as compared to firms requiring less debt financing. Similarly, Ferris, Jagannathan and Pritchard (2002) found a positive and significant association between the log of board size in 1995 and the ratio of market-to-book value for firms requiring debt financing.

Dalton et al. (1999) maintain that larger boards may offer higher levels of advice and counsel to the CEO. Hermalin and Weisbach (1988) suggest that independent non-executive directors serve as potential sources of counsel and add expertise and experience to the board, while Lorsch and MacIver (1989) similarly note that directors consider that one of their key duties during normal times is to advise the CEO. In fact, Adams and Mehran (2003) found that boards devote significant resources - up to 52 per cent of total director meetings - to activities that are not traditionally considered to be monitoring activities.

In the US context it has been found that, as the number of states in which a bank has operations increases, the board size increases, perhaps to accommodate representatives of the subsidiaries from different states (Adam \& Mehran, 2003). Agrawal and Knoeber (2001) found that firms that require more political advice have a higher proportion of outsiders with political connections on their board. It is therefore likely that while smaller boards are more effective at monitoring, board size will increase as the firm's advising requirements grow (Agrawal \& Knoeber, 2001).

Yermack (1996) suggests that the CEOs of diversified firms may require higher levels of advice compared to less diversified firms and that the need for advice may increase with the number of business segments. Thus, in diversified firms the board should be large enough to accommodate independent non-executive directors with backgrounds matching the disparate business interests of the firm, and who will also be able to advise the CEO on investment opportunities. It is therefore acknowledged internationally that board size and firm size are correlated (Yermack, 1996; Dalton et al., 1999). This finding may be explained in terms of the two prevailing governance theories.

From an agency perspective, larger companies require a greater number of directors in order to monitor and control a firm's activities (Yermack, 1996). From a resource dependence perspective, larger and diversified companies require access to a greater range of resources and firms will therefore appoint more directors to provide access to those resources (Nicholson \& Kiel, 2003). Consequently, derived from the predictions of both of these bodies of theory, hypothesis 2 is posited:

$\mathrm{H}_{2}$ : Board size is positively and significantly associated with firm performance.

Having reviewed the literature relating to the variables under study, the methods applied in this research are now introduced and discussed.

\section{Method}

For the study, published annual reports are used as the main source of data and statistical analysis is applied using a cross-sectional associative research design. The research design is chosen to match the appropriate processes required in the study (Leedy \& Ormrod, 2010). The study therefore adopts a quantitative approach and uses multiple regression analysis (MRA) as the appropriate statistical technique. Accordingly, the research design is also empirical in nature (Ryan, Scapens \& Theobald, 2002; Leedy \& Ormrod, 2010). Precedent is followed in order to build on previous work and to faithfully extend previous work into the South African context for testing.

\subsection{Measures}

In line with the precedent of other studies (Daily \& Dalton, 1993; Coles, McWilliams \& Sen, 2001; Bhagat \& Black, 2002), two measures of board composition/demographics are used. Firstly, 
the size of each board contained in the dataset is calculated. Secondly, each director is classified as either an executive (inside) director or an independent non-executive (outside) director. It is thus possible to calculate the percentage of non-executive directors on each board. The definition used in this work, that board composition is the percentage of independent non-executive directors who were members of the board (Rashid et al., 2010), is taken to satisfy the requirements of the definition of board composition as stipulated in the King III Report (Institute of Directors in Southern Africa (IOD), 2009). Board size is taken to refer to the total number of members serving on a firm's board. These definitions are therefore regarded to reflect the precedent of previous literature in the corporate governance field.

While there are many measures of firm performance (e.g. stakeholder satisfaction and intellectual capital (Clarkson, 1995)), the approach of Bhagat and Black (2002) and Nicholson and Kiel (2003) is followed by using three core financial measures of firm performance, namely, Tobin's $Q$, return on assets (ROA) and return on equity (ROE). Financial measures of a firm's financial performance may be classified into two key categories, namely, accounting-based measures and market-based measures (Nicholson \& Kiel, 2003).

Accounting-based measures of performance are historical and are characterised by a more backward and inward-looking focus (Cochran \& Wood, 1984). In contrast, market-based measures of a firm's performance relate to the overall value ascribed to the firm by the market (Nicholson \& Kiel, 2003). Such measures may not bear any relationship to asset valuations, current operations or even the firm's historical profitability (Muth \& Donaldson, 1998). Measures in this category include market-to-book ratio, Tobin's $Q$ (Barnhart, Marr \& Rosenstein, 1994) or constructed indices such as the Sharpe measure (Hoskisson, Johnson \& Moesel, 1994).

This study therefore uses both accounting and market-based measures. As regards the profitability of a firm's assets in terms of generating revenue, the net ROA managed is calculated as the ratio of net profit to total assets. In order to measure a firm's efficiency in using investment funds to create increased earnings, ROE is calculated as the ratio of net profit to equity. Finally, as a market-based variable, Tobin's $Q$ is calculated. In line with Bhagat and Black (2002), Tobin's $Q$ is denoted as follows:

Tobin's $Q=$ (Market Value (Equity) + Book Value (Assets) - Book Value (Equity))/Book Value (Assets)

Statistical predictions may often be improved by the use of more than one independent variable (Van Staden, 1998). The regression results therefore control for a number of factors that could have affected firm performance, board composition, or both. Control variables were therefore included, as per precedent in this literature (Bhagat \& Black, 2002).

In order to examine the relationship between board composition and firm performance, the following standard, or simultaneous MRA model is developed:

$Y i, t=\alpha+\beta 1 B D C O M P i, t+\beta 2 B D E X E C i, t+\beta 3 B D S I Z E i, t+\beta 4$ AGEi, $t+\beta 5$ SIZE1i, $t+\beta 6 S I Z E 2 i, t+\beta 7$ GROWTHi, $t+$ $\beta 8$ TASSETSi,t+ $\beta$ SSHFUNDSi, $t+\beta 10 N I N C O M E i, t+\beta 11$ RSHFUNDSi, $t+\beta 12$ INDUSTi, $t+\beta 13$ LISTEDi, $t+$ $\beta 14 \mathrm{KINGIII}+\varepsilon i, \mathrm{t}$

Where, Yi,t represents firm performance variables; ROAi,t, ROEi,t, and Tobin's Qi,t, which are for firm i in time t. BDCOMPi,t and BDEXECi,t are the board composition (percentage of nonexecutive to executive directors and number of executive directors, respectively), BDSIZEi, $t$ is the board size, and AGEi,t is the firm age. KINGIII is a dummy capturing the post King III time period. SIZE1i,t and SIZE2i,t represent the firm size measured by sales and market capitalisation, and GROWTHi,t is the firm's growth as represented by the changes in sales and operating revenue/turnover.Other control variables include total assets (TASSETSi,t), shareholder funds (SHFUNDSi,t), industry dummies for different industries (INDUSTi,t) and listing status (LISTEDi,t). Finally, $\alpha$ is the intercept, $\beta$ is the regression coefficient and $\boldsymbol{\varepsilon}$ is the error term. Variables were adjusted for inflation before inclusion in the analysis.

Multiple linear regression analysis, however, cannot imply a cause-and-effect relationship (Montgomery, Peck \& Vining, 2006), only the most likely associations between a dependent variable and several independent variables (Coakes \& Steed, 2001). Subsequently, the 
assumptions of the model are tested (Sheather, 2009). The linearity of the dependent and independent variables is tested by observing scattergrams of standardised residuals against the predicted values. Non-discernible patterns in the plots of the residuals are taken to indicate the acceptability of the data. The Durbin-Watson test statistics results are deemed acceptable. In order to test for homoscedasticity (Gamst, Meyers \& Guarino, 2008), a scatterplot of the standardised residuals is plotted against the firm performance variables. The normality of errors is tested by using a normal probability plot (P-P) of the standardised residuals and histograms of the residuals. Histograms are used to display interval-ratio data and these offer checks for skewness, kurtosis and modal patterns (Cooper \& Schindler, 2001). The tested relationships are also tested for multicollinearity using computed variance inflation factors (VIFs) and eigenvalues in SPSS. On the basis of these tests, the assumptions of the MRA models tested are deemed to have been met.

\subsection{The population and sample of the study}

The sampling frame comprises all JSE listed companies for the 2006 to 2012 financial years. All companies from across all the industrial sectors that were listed on the JSE from 2006 to 2012 are included. Firm performance is measured using the statutory annual reports, or the published annual reports of companies listed on the JSE Securities Exchange from the 2006 to the 2012 fiscal years covering an average of 338 companies, based on usable data. The data is sourced from the published annual reports on each company's website and is downloaded from the OSIRIS financial database directly into Microsoft Excel.

\subsection{Data analysis-OSIRIS}

The data collected from the OSRIS financial database is downloaded in Excel workbooks containing seven worksheets each representing a financial year end. Various different multiple regressions are run, including fixed effects, random effects, ordinary least squares (OLS), generalised least squares (GLS) and a dynamic panel. The most robust of these was the OLS model and this is therefore used in the analysis. The year 2010 (when King III came into effect) was used as the base year.

\subsection{Validity}

Both external and internal validity (Leedy \& Ormrod, 2005) were carefully considered, with particular attention being paid to measurement validity, internal, external and ecological validity (Bryman \& Bell, 2007). As regards this study, we focused primarily on measurement validity in terms of using different control variables. However, the internal validity was reflected in the correlation test between different variables in order to examine the relationships between them. Thus, various regression diagnostics, including tests for normality, heteroscedasticity and multicollinearity were carried out to enhance internal validity of the regression model. Reliability is also ensured (Bryman \& Bell, 2007); all data is extracted from audited published annual reports, and transparency, relevance and reliability are taken to be of utmost importance.

\subsection{Assumptions}

Certain assumptions are made. It is assumed that the total number of firms included in the sample is sufficient to ensure adequate data on corporate financial reporting and performance and also that the corporate governance information is communicated candidly and truthfully by the firms. False data would have a detrimental effect on the study's results.

\subsection{Data delimitations}

The study uses public listed companies on the Johannesburg Stock Exchange only and focuses on the Code of Governance Principles for South Africa 2009(Institute of Directors in Southern Africa (IOD), 2009). Thus, detailed data on the budgets and forecasts of specific business units are not discussed. 


\section{Results}

\subsection{Descriptive statistics}

As Figure 1 below shows, the majority of the companies were listed between 1994 and 2007 with more than 60 per cent being incorporated in 1998 following the release of the King I and II reports.

The mean percentage of independent non-executive directors on the boards of directors of South African companies listed on the JSE securities exchange before King III is 50 per cent After King III, this figure goes up to 53 per cent with a median of 57 per cent. These results are consistent with the findings of Vafas and Theodorou (1998), who report that of the 250 publicly listed firms they survey in the United Kingdom (UK) context, the percentages of independent nonexecutive and executive directors on the boards of directors are 61 per cent and 39 per cent respectively.

Figure 1

Date of incorporation/listing on JSE

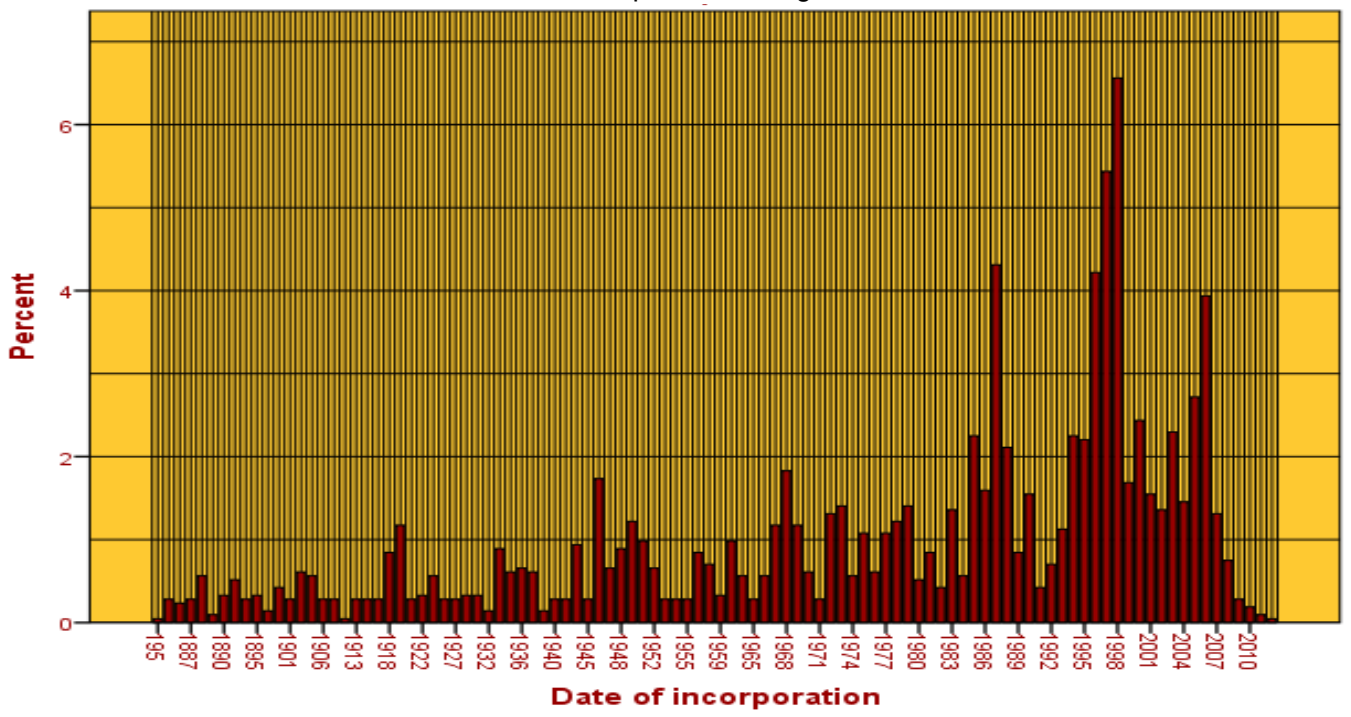

Of all the firms included in this study, the mean board size is approximately 12.87 before King III, rising marginally to 13.54 after King III. These firms had a maximum board size of 24 and an average standard deviation of 4 . The mean company age is 39 years before King III but relatively lower after King III at 36 years.

\subsection{Results of hypothesis testing}

$H_{1}$ : Board composition (the proportion of outside independent directors) is significantly and positively associated with firm performance

The percentage of independent non-executive directors variable is not significantly associated with Tobin's $Q$ (Table $1 ; t=0.973 ; \mathrm{p}<0.331$ ), nor ROA (Table $2 ; t=-1.182 ; \mathrm{p}<0.237$ ) at the five percent level of significance; this relationship, however, is positively significant for ROE (Table $2 ; t=$ 2.006; $\mathrm{p}<0.045$ ). Overall, these findings do not support the prediction of a significant and positive association between the percentage of non-executive directors and firm performance found in other empirical studies (Weisbach, 1988; Byrd \& Hickman, 1992; Brickley, Coles \& Terry, 1994), which have generally argued for the benefits of including more independent non-executive directors on boards on the basis of their beneficial monitoring and advisory functions on behalf of firm shareholders. Insufficient evidence exists to support the hypothesis. This result is also not 
consistent with the findings of Baysinger and Butler (1985) and Rosenstein and Wyatt (1994), who show that the market rewards firms for appointing more outside directors. On the other hand, these findings are consistent with the findings of Agrawal and Knoeber (1996), who suggest that larger numbers of independent directors may not be related to performance; that boards expanding for political reasons typically have too many outsiders on the board which does not improve performance. It is possible a larger proportion of non-executive directors is positively associated with ROE, but this result stands in contrast to work by Fosberg (1989), who found a negative relationship between board composition and $\mathrm{ROE}$ as a firm performance measure. It is acknowledged, however, that the South African context may differ in certain ways from other contexts. Further research may better explain the lack of an overall relationship between percentage of non-executive directors and performance measured by Tobin's Q as well as return to assets in the South African context.

The overall results, however, are consistent with the findings of earlier studies which have found no significant relationship between board composition and company performance (Rechner \& Dalton, 1986; Fosberg, 1989; Daily \& Dalton, 1993; Barnhart et al., 1994; Grace, Ireland \& Dunstan, 1995; Dalton et al., 1998; Cho \& Kim, 2007; Finegold et al., 2007). Despite the fact that studies by Fama and Jensen (1983), Baysinger and Butler (1985) and Baysinger and Hoskinsson (1990) have asserted that the effectiveness of a board depends on an optimal mix of executive and non-executive directors, the historical dearth of theory on the determinants of an optimal board composition (Hermalin \& Weisbach, 2003) is also consonant with these findings. Agency theory predicts agency costs can be reduced by having a higher proportion of independent non-executive directors (Boyd, 1990; Johnson, Daily, \& Ellastrand, 1996; Hillman \& Dalziel, 2003); to the extent that this may contribute to firm performance in this context. The findings offer little evidence in support of this as a testable empirical effect. Similarly, to the extent that a higher proportion of independent non-executive directors may provide resources advantages that contribute to firm performance, as predicted by resource dependence theory (Pfeffer, 1972; Pfeffer \& Salancik, 1978; Boyd, 1990; Daily \& Dalton, 1994; Gales \& Kesner, 1994; Hillman, Cannella, \& Paetzold, 2000), the findings provide little in the way of evidence to support this as a dominant effect.

There are other potential explanations for these findings. It is possible that within these boards, certain constraints exist to the transmission of an increase in independence to company performance. It may therefore be possible that 'beneath' the level of the net effect is a range of subordinate effects that may render the influence of independent directors ineffective in their contribution to performance. Some directors classified as independent may not be truly independent of management (Bhagat \& Black, 2002), or may know too little about the business, and may, hence, be oversupportive of a CEO (Nicholson \& Kiel, 2003). Well-known persons with limited business experience, who often hold multiple directorships, may not be sufficiently effective as directors (Bhagat \& Black, 2002). The rotation of board members may not occur sufficiently, or may occur in a way that valuable skills are not retained, constraining the continuity of knowledge and experience, or new directors with new ideas and expertise may not be effectively introduced (IOD, 2009). Independent directors who have served for too long may also become less vigorous monitors (Bhagat \& Black, 2002). A final possibility is that independent directors may add value to a board, but only if they are embedded in an appropriate board committee structure (Deloitte, 2013). Incompetent or unsuitable directors should be removed from office, while taking relevant legal and other requirements into consideration (IOD, 2009). It is, however, acknowledged the objective of this research is limited to a test of the net associations between the degree of numerical independence of boards and company performance. On the basis of these findings, further research is recommended to investigate the multitude of causal effects that run beneath the level of net effects. Notwithstanding these effects, this study provides evidence in support of the notion that the numerical independence of boards is not significantly (and not positively) related to company performance in this context during the period covered by the data. The findings relating to board size and company performance are now reported and discussed. 
Table 1

Results for tests: OLS dependent variable Tobin's $Q$

\begin{tabular}{|c|c|c|c|c|c|}
\hline Variable & $\begin{array}{l}\text { Unstandardised } \\
\text { B }\end{array}$ & Std. error & $\begin{array}{l}\text { Standardised } \\
\text { beta }\end{array}$ & $\mathbf{t}$ & Significance \\
\hline (Constant) & 0.146 & 0.103 & & 1.419 & 0.156 \\
\hline Change in operating revenue//Turnover & $-3.38 E-09$ & 0.00 & 0.037 & 0.198 & 0.843 \\
\hline Total assets & $1.80 \mathrm{E}-10$ & 0.00 & 0.036 & 0.426 & 0.67 \\
\hline Shareholders' funds & $-2.5 \mathrm{E}-08$ & 0.00 & -0.517 & -8.597 & 0.00 \\
\hline Market capitalisation & $1.16 \mathrm{E}-08$ & 0.00 & 0.531 & 11.794 & 0.00 \\
\hline Sales & $8.85 \mathrm{E}-10$ & 0.00 & 0.022 & 0.129 & 0.897 \\
\hline Executive directors & 0.01 & 0.012 & 0.059 & 0.797 & 0.425 \\
\hline Percentage of independent non-executive directors & 0.002 & 0.002 & 0.043 & 0.973 & 0.331 \\
\hline Industry=AGRICULTURE \& FISHING & -0.161 & 0.101 & -0.035 & -1.6 & 0.11 \\
\hline Industry=CONSTRUCTION & -0.118 & 0.059 & -0.047 & -1.831 & 0.067 \\
\hline Industry=DIVERSIFIED HOLDING COMPANIES & -0.149 & 0.068 & -0.052 & -2.192 & 0.028 \\
\hline $\begin{array}{l}\text { Industry=FINANCIAL SERVICES AND REAL } \\
\text { ESTATE }\end{array}$ & -0.058 & 0.045 & -0.046 & -1.283 & 0.199 \\
\hline Industry=HEALTH CARE & 0.113 & 0.076 & 0.035 & 1.496 & 0.135 \\
\hline Industry=HOTELS AND RESTAURANTS & 0.182 & 0.078 & 0.054 & 2.343 & 0.019 \\
\hline Industry=MANUFACTURING INDUSTRY & -0.027 & 0.049 & -0.016 & -0.555 & 0.579 \\
\hline Industry=MINING \& EXTRACTING INDUSTRIES & 0.02 & 0.051 & 0.012 & 0.404 & 0.686 \\
\hline $\begin{array}{l}\text { Industry=TELECOMMUNICATION AND } \\
\text { ELECTRONICS }\end{array}$ & -0.073 & 0.049 & -0.058 & -1.483 & 0.138 \\
\hline Industry=TRANSPORT SERVICES & -0.27 & 0.102 & -0.058 & -2.649 & 0.008 \\
\hline Listed & 0.064 & 0.044 & 0.03 & 1.431 & 0.153 \\
\hline After King 3 & -0.102 & 0.024 & -0.089 & -4.223 & 0.00 \\
\hline Board size & -0.002 & 0.007 & -0.015 & -0.232 & 0.816 \\
\hline Company age & 0.001 & 0.00 & 0.036 & 1.636 & 0.102 \\
\hline
\end{tabular}

Note: Data is adjusted for inflation; dependent variable is log of Tobin's $Q$

$\mathrm{H}_{2}$ : Board size is positively and significantly associated with firm performance.

Board size is not found to be significantly associated with Tobin's $Q$ (Table $1 ; t=-0.232$; $\mathrm{p}<0.816$ ). In line with the findings of Jensen (1993), Lipton and Lorsch (1992) and Yermack (1996), these results suggest that larger boards are not necessarily associated with higher levels of Tobin's $Q$, at least not in the context over this period. As in the case of Tobin's $Q$, the size of the board is also found not to be significantly associated with ROE (Table $3 ; t=-0.877 ; \mathrm{p}<0.38$ ). In contrast, board size is found to be positively associated with ROA (Table $2 ; t=1.696 ; \mathrm{p}<0.09$ ), but at only just within the ten percent level of significance. Overall, a lack of evidence is found to support the hypothesis across the three measured dependent variables.

The results therefore do not rule out the view that larger boards may face challenges in the form of poor internal communication and decision-making processes (Yermack, 1996). It is also possible that larger boards may suffer from the development of factions and coalitions that lead to group conflict or might result in firms reacting slowly or indecisively in a crisis (Huse, 2007), which might militate against any other positive influence of board size on firm performance. Other arguments have been advanced to the effect that larger and more diverse boards may be more easily manipulated than smaller boards on the grounds that it is easier for the CEO to gain dominance over the board by, for example, coalition building (Huse, 2007).

This result is to some extent consistent with the findings of other researchers (Lipton \& Lorsch, 1992; Jensen, 1993) who have argued that large boards can be less effective and easier for the CEO to control than smaller boards. When a board becomes too big, it can become difficult to coordinate and can face process problems, or increase the possibility of free riding by individual directors, and thereby constrain the effectiveness of decision-making processes (Huse, 2007; 
Sanda et al., 2011). Other empirical research supports this argument; for example Yermack (1996) found that, in the case of large US industrial corporations, the market values firms with smaller boards more highly than those with larger boards. Similarly, in the African continental context, a Nigerian study by Sanda et al. (2011) found firm performance to be positively associated with small as opposed to large boards.

In terms of the positive yet borderline non-significant association between ROA and board size, resource dependence theory has been used to argue in favour of a positive relationship between board size and corporate financial performance (Huse, 2007). Resource dependence theory argues that boards form environmental linkages in order to secure resources, which a large board would better be able to do than a small board (Huse, 2007). It is therefore possible that in this context, the greater the need for external linkages the larger the board should be (Pfeffer \& Salancik, 1978). In addition, Huse (2007) argues that interlocking directorates are expected to facilitate both communication and inter-organisational coordination. Similarly, a larger board might offer a greater 'control' function (Boyd, 1990; Johnson, Daily, \& Ellastrand, 1996; Hillman \& Dalziel, 2003), supporting agency theory predictions of agency cost reductions transmitting to return to equity. However, given the positive coefficient for board size in its relationship with ROA is outside of the five percent threshold for significance, this result is treated with caution here, and not taken as evidence in support of these perspectives.

Table 2

Results: OLS dependent variable: return on total assets (\%)

\begin{tabular}{|c|c|c|c|c|c|}
\hline Variable & $\begin{array}{c}\text { Unstandardised } \\
\text { B }\end{array}$ & Std. Error & $\begin{array}{l}\text { Standardised } \\
\text { beta }\end{array}$ & $\mathbf{t}$ & Significance \\
\hline (Constant) & 9.624 & 2.574 & & 3.739 & 0.000 \\
\hline Change in operating revenue/turnover & 3.06E-07 & 0.00 & 0.277 & 1.601 & 0.11 \\
\hline Total assets & $-2.88 \mathrm{E}-08$ & 0.00 & -0.189 & -2.484 & 0.013 \\
\hline Shareholders' funds & $-2.2 \mathrm{E}-07$ & 0.00 & -0.149 & -2.661 & 0.008 \\
\hline Market capitalisation & $1.89 \mathrm{E}-07$ & 0.00 & 0.288 & 6.93 & 0.00 \\
\hline Sales & $-2.77 \mathrm{E}-07$ & 0.00 & -0.235 & -1.477 & 0.14 \\
\hline Executive directors & -0.248 & 0.324 & -0.051 & -0.766 & 0.444 \\
\hline Percentage of independent non-executive directors & -0.049 & 0.041 & -0.048 & -1.182 & 0.237 \\
\hline Industry=AGRICULTURE \& FISHING & -1.309 & 2.887 & -0.01 & -0.453 & 0.65 \\
\hline Industry=CONSTRUCTION & -6.035 & 1.643 & -0.091 & -3.673 & 0.00 \\
\hline Industry=DIVERSIFIED HOLDING COMPANIES & -4.193 & 1.831 & -0.053 & -2.29 & 0.022 \\
\hline $\begin{array}{l}\text { Industry=FINANCIAL SERVICES AND REAL } \\
\text { ESTATE }\end{array}$ & -4.629 & 1.252 & -0.129 & -3.697 & 0.00 \\
\hline Industry=HEALTH CARE & -6.02 & 2.118 & -0.064 & -2.842 & 0.005 \\
\hline Industry=HOTELS AND RESTAURANTS & -0.72 & 2.192 & -0.006 & -0.328 & 0.743 \\
\hline Industry=MANUFACTURING INDUSTRY & -2.954 & 1.365 & -0.062 & -2.165 & 0.031 \\
\hline Industry=MINING \& EXTRACTING INDUSTRIES & -8.668 & 1.411 & -0.179 & -6.145 & 0.00 \\
\hline $\begin{array}{l}\text { Industry=TELECOMMUNICATION AND } \\
\text { ELECTRONICS }\end{array}$ & -1.871 & 1.371 & -0.039 & -1.364 & 0.173 \\
\hline Industry=TRANSPORT SERVICES & -6.181 & 2.848 & -0.046 & -2.171 & 0.03 \\
\hline Listed & 3.588 & 1.172 & 0.062 & 3.06 & 0.002 \\
\hline After King 3 & -5.325 & 0.669 & -0.161 & -7.961 & 0.00 \\
\hline Board size & 0.317 & 0.187 & 0.104 & 1.696 & 0.09 \\
\hline Company age & 0.013 & 0.011 & 0.024 & 1.143 & 0.253 \\
\hline
\end{tabular}

Note: Data adjusted for inflation

The coefficient for the King III variable, however, displays a negative relationship with Tobin's $Q$ $(t=-4.223 ; \mathrm{p}<0.001), \operatorname{ROA}(t=-7.961 ; \mathrm{p}<0.001)$ and $\operatorname{ROE}(t=-4.745 ; \mathrm{p}<0.001)$. This result is not congruent with the predictions of the literature (Cliffe Dekker Hofmeyer, 2013). Negative performance following the implementation of King III might have captured time-related industry- 
specific downturns over the period of the study post King III. Nonetheless, this was considered a useful control variable as a proxy for governance changes. Nevertheless, further research is recommended before suggestions can be made that implementing King III provisions in this context may be negatively associated with certain dimensions of firm performance. This finding is taken to highlight the need for further research to establish the causal relationships underpinning these associations.

Table 3

OLS dependent variable: Return on equity (\%)

\begin{tabular}{|c|c|c|c|c|c|}
\hline \multirow[t]{2}{*}{ Model equation 3} & \multicolumn{2}{|c|}{$\begin{array}{l}\text { Unstandardized } \\
\text { coefficients }\end{array}$} & \multirow{2}{*}{\begin{tabular}{|c|}
$\begin{array}{c}\text { Standardized } \\
\text { coefficients }\end{array}$ \\
Beta \\
\end{tabular}} & \multirow[t]{2}{*}{$\mathbf{t}$} & \multirow[t]{2}{*}{ Sig. } \\
\hline & B & Std. error & & & \\
\hline (Constant) & 3.208 & 10.707 & & .3 & 0.764 \\
\hline Change in operating revenue/Turnover & $-3.06 \mathrm{E}-07$ & 0.00 & -0.069 & -0.385 & 0.7 \\
\hline Total assets & $2.23 \mathrm{E}-08$ & 0.00 & 0.036 & 0.462 & 0.644 \\
\hline Shareholders' funds & $-8.92 \mathrm{E}-07$ & 0.00 & -0.148 & -2.557 & 0.011 \\
\hline Market capitalisation & $3.48 \mathrm{E}-07$ & 0.00 & 0.132 & 3.062 & 0.002 \\
\hline Sales & $5.94 \mathrm{E}-07$ & 0.00 & 0.125 & 0.76 & 0.447 \\
\hline Executive Directors & 1.421 & 1.349 & 0.073 & 1.053 & 0.292 \\
\hline Percentage of independent non-executive directors & 0.345 & 0.172 & 0.085 & 2.006 & 0.045 \\
\hline Industry=AGRICULTURE \& FISHING & -5.344 & 12.009 & -0.01 & -0.445 & 0.656 \\
\hline Industry=CONSTRUCTION & -10.826 & 6.835 & -0.04 & -1.584 & 0.113 \\
\hline Industry=DIVERSIFIED HOLDING COMPANIES & -13.995 & 7.616 & -0.044 & -1.838 & 0.066 \\
\hline Industry=FINANCIAL SERVICES AND REAL ESTATE & -0.808 & 5.209 & -0.006 & -0.155 & 0.877 \\
\hline Industry=HEALTH CARE & -11.687 & 8.81 & -0.031 & -1.327 & 0.185 \\
\hline Industry=HOTELS AND RESTAURANTS & -2.515 & 9.119 & -0.006 & -0.276 & 0.783 \\
\hline Industry=MANUFACTURING INDUSTRY & -0.244 & 5.677 & -0.001 & -0.043 & 0.966 \\
\hline Industry=MINING \& EXTRACTING INDUSTRIES & -4.625 & 5.092 & -0.024 & -0.908 & 0.364 \\
\hline Industry=TELECOMMUNICATION AND ELECTRONICS & -4.68 & 5.705 & -0.025 & -0.82 & 0.412 \\
\hline Industry=TRANSPORT SERVICES & -9.54 & 11.846 & -0.017 & -0.805 & 0.421 \\
\hline Listed & 2.858 & 4.877 & 0.012 & 0.586 & 0.558 \\
\hline After King 3 & -13.204 & 2.783 & -0.099 & -4.745 & 0.00 \\
\hline Board size & -0.682 & 0.777 & -0.056 & -0.877 & 0.38 \\
\hline Company age & -0.015 & 0.047 & -0.007 & -0.324 & 0.746 \\
\hline
\end{tabular}

Note: Data adjusted for inflation

\section{Conclusions}

The objective of this study was to empirically test the relationships between company performance and certain measures of corporate governance, namely, the board composition and board size of all listed public firms on the JSE from 2006 to 2012. The study follows similar research conducted by Bhagat and Black (2002) and Yermack (1996) in the US, but extends this stream of research into the South African context.

This study revealed mixed results; contrary to the predictions of both agency and resource dependence theories. Majority findings suggest that over the period of the study proportions of non-executive directors are not significantly associated with Tobin's Q and ROA, and board size is not significantly associated with all three of these performance measures in the South African context. Supporting agency and resource dependence theories directly, is the minority finding that ROE is positively associated with proportion of non-executive directors. However, given this is a minority finding, any such interpretation requires caution. Agency and resource dependence theory are not taken to be supported by the positive association between board size and ROA as this is outside the five percent level of significance. It is concluded, however, that the South African 
context may differ from other global contexts; knowledge of the overarching lack of significant relationships for both board size and greater proportions of non-executive directors with company performance may be an important insight if borne out by further research. Practical implications may derive from this finding; when appointing non-executive directors, more careful consideration may be needed of the benefits they may bring, be this in terms of independent expert business knowledge and experience, or other sources of advantage to boards, and the companies they manage. A more active process of mapping these benefits and understanding the causal channels and mechanisms through which they work may increase a company's chances of benefitting from larger numbers of non-executive board members, as predicted by both agency and resource dependency theories.

\section{Recommendations for further research}

This research study focuses exclusively on board composition (defined by the percentage representation of independent non-executive directors on the board) and board size and firm performance. Further research could be conducted in other areas such as board structure with a focus on director remuneration, directorship positions held, age, director qualifications, and gender diversity among directors. In addition, this research study examines the association between board composition and firm performance within an isolated corporate governance setting and, thus, it could be extended to consider nations with a different corporate governance structure from South Africa. Further qualitative research might offer important insights that build on these findings, and make explicit the mechanisms through which independent non-executive board members and larger boards may contribute to performance, so firms can better apply this knowledge.

\section{$9 \quad$ Limitations}

There are certain limitations to this study. The study focuses on board independence and board size as important variables in terms of which to examine the correlation between board composition and firm performance, while other characteristics such as tenure, diversity, age, gender, qualification and the background of directors are not examined. In addition, financial ratios may not entirely reflect the important role of the board in corporate governance. Firm performance is a result of the interaction between a host of different company-level and socioeconomic factors. Thus, besides the factors considered in this study, there are many other factors including strategy, network and social environment that may need to be taken into account. Nevertheless, this study sought to test two specific dimensions of the governance-firm performance relationship in this context, and it is hoped that future research will build on this and seek to unearth the causal mechanisms that are reflected in these findings.

\section{References}

ADAMS, R. \& MEHRAN, H. 2003. Is corporate governance different for bank holding companies? Economic Policy Review, (19320426)9:123-142.

AGRAWAL, A. \& KNOEBER, C.R. 1996. Firm performance and mechanism to control agency problems between managers and shareholders. Journal of Financial and Quantitative Analysis, 31:377-397.

AGRAWAL, A. \& KNOEBER, C.R. 2001. Do some outside directors play a political role? Journal of Law and Economics, 14:179-198.

ANDREASSON, S. 2011. Understanding corporate governance reforms in South Africa: Anglo-American Divergence, the King Reports, and hybridization. Business \& Society, 50(4):647-673.

BARNHART, S., MARR, W. \& ROSENSTEIN, S. 1994. Firm performance and board composition: Some new evidence. Managerial and Decision Economics, 15:329-340.

BAYSINGER, B. \& BUTLER, H. 1985. Corporate governance and the board of directors: Performance effects of changes inboard composition. Journal of Law, Economics and Organization, 1:101-134. 
BAYSINGER, B. \& HOSKISSON, R. 1990. The composition of boards of directors and strategic control. Academy of Management Review, 15:72-87.

BERLE, A. \& MEANS, G. 1932. The modern corporation and private property. New York: Macmillan. BERMIG, A. \& FRICK, B. 2010. Board size, board composition and firm performance: Empirical evidence from Germany. Working Paper (University of Paderborn), 10 June.

BHAGAT, S. \& BLACK, B. 1999. The uncertain relationship between board composition and firm performance. Business Lawyer, 54(3):921-963.

BHAGAT, S. \& BLACK, B. 2002. The non-correlation between board independence and long-term firm performance. Journal of Corporation Law, 27(2):231-273.

BOOTH, J.R. \& DELI, D.N. 1999. On executives of financial institutions as outside directors. Journal of Corporate Finance, 5(3):227-250.

BOYD, B. 1990. Corporate linkages and organizational environment: A test of the resource dependence model. Strategic Management Journal, 11:419-430.

BRICKLEY, J.A., COLES, J.L. \& TERRY, R.L. 1994. Outside directors and the adoption of poison pills. Journal of Financial Economics, 35:371-390.

BRYMAN, A. \& BELL, E. 2007. Business research methods. (2 ${ }^{\text {nd }}$ ed.) Oxford: Oxford University Press. BYRD, J.W. \& HICKMAN, K.A. 1992. Do outside directors monitor managers? Evidence from tender offer bids. Journal of Financial Economics, 32:195-222.

CHO, D. \& KIM, J. 2007. Outside directors, ownership structure and firm profitability in Korea. Corporate Governance: An International Review, 15(2):239-250.

CLARKSON, M.E. 1995. A stakeholder framework for analysing and evaluating corporate social performance. Academy of Management Review, 20(1):92-117.

CLIFFE DEKKER HOFMEYR. 2013. King III in a nutshell. http://www.cliffedekkerhofmeyr. $\mathrm{com} /$ export/sites/cdh/en/legal/sectors/downloads/Cliffe-Dekker-Hofmeyr-King-III-in-a-Nutshell.pdf [accessed October 2013].

COAKES, S. \& STEED, L. 2001. SPSS analysis without anguish Version 10. Australia: John Wiley and Sons.

COCHRAN, P.L. \& WOOD, R.A. 1984. Corporate social responsibility and financial performance. Academy of Management Journal, 27(1):42-56.

COLES, J.W., MCWILLIAMS, V.B. \& SEN, N. 2001. An examination of the relationship of governance mechanisms to performance. Journal of Management, 27(1):23-50.

COOPER, D. \& SCHINDLER, P. 2001. Business research methods. ( $7^{\text {th }}$ ed.) New York: McGraw-Hill Higher Education.

DAILY, C.M. \& DALTON, D.R. 1993. Board of directors leadership and structure and corporate performance in entrepreneurial firms. Journal of Business Ventures, 7(5):375-386.

DAILY, C. \& DALTON, D. 1994. Bankruptcy and corporate governance: The impact of board composition and structure. Academy of Management Journal, 37:1603-1617.

DAILY, C.M. \& JOHNSON, J. L. 1997. Sources of CEO power and firm financial performance: A longitudinal assessment. Journal of Management, 23(2):97-112.

DALTON, D., DAILY, C., ELLSTRAND, A. \& JOHNSON, J. 1998. Meta-analytic review of board composition, leadership structure, and financial performance. Strategic Management Journal, 19:269-290.

DALTON, D., DAILY, C., JOHNSON, J. \& ELLSTRAND, A, 1999. Number of directors and financial performance: A meta-analysis. Academy of Management Journal, 42:674-686.

DELOITTE. 2013. Duties of Directors - April 2013. http://www.deloitte.com/assets/DcomSouthAfrica/ Local\%20Assets/Documents/NED Duties of Directors.pdf [accessed November 2013].

DULEWICZ, V. \& HERBERT, P. 2004. Does the composition and practice of boards and directors bear any relationship to the performance of the companies? Corporate Governance, 12(3):263-280.

EISENHARDT, K. 1989. Agency theory: An assessment and review. Academy of Management Review, 14:57-74.

EKLUND, J.E., PALMBERG, J. \& WIBERG, D. 2009. Ownership structure, board composition and investment performance. CESIS Electronic Working Paper Series, Paper no. 172. 
FAMA, E. 1980. Agency problems and the theory of the firm. Journal of Political Economy, 88:288-307. FAMA, E. \& JENSEN, M. 1983. Separation of ownership and control. Journal of Law and Economics, 26:301-325.

FERRIS, S.P., JAGANNATHAN, M. \& PRITCHARD, A.C. 2002. Too busy to mind the business? Monitoring by directors with multiple board appointments. Earlier version. http:/papers.ssrn.com/abstract=167288 (Social Science Research Network) [accessed November 2016]. FINEGOLD, D., BENSON, G.S. \& HECHT, D. 2007. Corporate boards and company performance: Review of research in light of recent reforms. Blackwell, 15(5):865-878.

FOSBERG, R.H. 1989. Outside directors and managerial monitoring. Akron Business and Economic Review, 20(2):24-32.

GALES, L. \& KESNER, I. 1994. An analysis of board of director size and composition in bankrupt organizations. Journal of Business Research, 30:271-282.

GAMST, G., MEYERS, L.S. \& GUARINO, A.J. 2008. Analysis of variance designs: A conceptual and computational approach with SPSS and SAS. New York: Cambridge University Press.

GRACE, M., IRELAND A. \& DUNSTAN, K. 1995. Board composition, non-executive directors: Characteristics and corporate financial performance. Asia Pacific Journal of Accounting, 2:121-137. HERMALIN, B.E. \& WEISBACH, M.S. 1988. The determinants of board composition. Rand Journal of Economics, 19:589-606.

HERMALIN, B. \& WEISBACH, M. 2003. Boards of directors as endogenously determined institutions: A survey of the economy literature. Economy Policy Review, 9(1):7-26.

HILLMAN, A.J. \& DALZIEL, T. 2003. Boards of directors and firm performance: Integrating agency and resource dependence perspectives. Academy of Management Review, 28(3):383-396.

HILLMAN, A., CANNELLA, A. \& PAETZOLD, R. 2000. The resource dependence role of corporate directors: Strategic adaptation of board composition in response to environmental change. Journal of Management Studies, 37:235-256.

HILLMAN, A., KEIM, G. \& LUCE, R. 2001. Board composition and stakeholder performance: Do stakeholder directors make a difference? Business \& Society, 40:295-314.

HOSKISSON, R.E., JOHNSON, R.A. \& MOESEL, D.D. 1994. Corporate divestiture intensity in restructuring firms: Effects of governance, strategy, and performance. Academy of Management Journal, 37(5):1207-1251.

HUSE, M. 2007. Boards, governance and value creation: The human side of corporate governance. New York: Cambridge University Press.

INSTITUTE OF DIRECTORS IN SOUTHERN AFRICA (IOD). 2009. King report on corporate governance for South Africa. http://www.iodsa.co.za/corporate.htm [accessed November 2013].

JENSEN, M. 1993. The modern industrial revolution, exit and the failure of internal control systems. Journal of Finance, 8:831-880.

JENSEN, M. \& MECKLING, W. 1976. Theory of the firm: Managerial behaviour, agency costs and ownership structure. Journal of Financial Economics, 3:305-360.

JOHNSON, J., DAILY, C. \& ELLSTRAND, A. 1996. Boards of directors: A review and research agenda. Journal of Management, 22:409-438.

JOHNSON, R. \& GREENING, D. 1999. The effects of corporate governance and institutional ownership on corporate social performance. Academy of Management Journal, 42:564-580.

KLEIN, A. 1998. Firm performance and board committee structure. Journal of Law and Economics, 41:137165.

KRIVOGORSKY, V. 2006. Ownership, board structure and performance in continental Europe. International Journal of Accounting, 41(2):176-197.

KYEREBOAH-COLEMAN, A. \& BIEKPE, N. 2005. Corporate governance and the performance of microfinance institutions (MFIs) in Ghana. Working paper, UGBS, Legon.

LEEDY, P.D. \& ORMROD, J.E. 2005. Practical research: Planning and design. Harlow, UK: Pearson. LEEDY, P.D. \& ORMROD, J.E. 2010. Practical research: Planning and design. Upper Saddle River, NJ: Merril Pearson Education. 
LIPTON, M. \& LORSCH, J. 1992. A modest proposal for improved corporate governance. Business Lawyer, 1:59-77.

LORSCH, J. \& MACIVER, E. 1989. Pawns or potentates: The reality of America's corporate boards. Cambridge, MA: Harvard Business School Press.

LUOMA, P. \& GOODSTEIN, J. 1999. Stakeholders and corporate boards: Institutional influences on board composition and structure. Academy of Management Journal, 42:553-563.

MACAVOY, P.W. \& MILLSTEIN, I.M. 1999. The active board of directors and its effect on the performance of the large publicly traded corporation. Journal of Applied Corporate Finance, 11(4):8-20.

MACE, M. 1971. Directors: Myth and reality. Boston, MA: Harvard Business School Press.

MAK, Y.T. \& LI, Y. 2001. Determinants of corporate ownership and board structure: Evidence from Singapore. Journal of Corporate Finance, 71:235.

MIZRUCHI, M. 1983. Who controls whom? An examination between management and boards of directors in large American corporations. Academy of Management Review, 8:426-435.

MONTGOMERY, D.C., PECK, E.A. \& VINING, G.G. 2006. Introduction to linear regression. (4 $4^{\text {th }}$ ed.) New York: Wiley\& Sons Inc.

MUTH, M. \& DONALDSON, L. 1998. Stewardship theory and board structure: A contingency approach. Corporate Governance: An International Review, 6(1):5-28.

NICHOLSON, G.J. \& KIEL, G.C. 2003. Board composition and corporate performance: How the Australian experience informs contrasting theories of corporate governance. Corporate Governance: An International Review, 11(3):189-205.

NICHOLSON, G.J. \& KIEL, G.C. 2007. Can directors impact performance? A case-based test of three theories of corporate governance. Corporate Governance: An International Review, 15(4):585-608.

PABLO, A., VALENTIN, A. \& FELIX, L. 2005. Corporate boards in OECD countries: Size, composition, functioning and effectiveness. Journal of Corporate Governance, 13(2):197-210.

PANASIAN, C., PREVOST, A.K. \& BHABRA, H.S. 2008. Voluntary listing requirements and corporate performance: The case of the Dey report and publicly listed Canadian firms. The Financial Review, 43: 129-157.

PEARCE, J. \& ZAHRA, S. 1992. Board composition from a strategic contingency perspective. Journal of Management Studies, 29:411-438.

PFEFFER, J. 1972. Size and composition of corporate boards of directors: The organization and its environment. Administrative Science Quarterly, 17:218-228.

PFEFFER, J. \& SALANCIK, G. 1978. The external control of organizations: A resource-dependence perspective. New York: Harper \& Row.

RASHID, A. 2011. Board composition, board leadership structure and firm performance: Evidence from Bangladesh. A paper for inclusion in the Accounting and Finance Association Australia and New Zealand Annual Conference Adelaide, 5-7 July.

RASHID, A., DE ZOYSA, A., LODH, S. \& RUDKIN, K. 2010. Board composition and firm performance: Evidence from Bangladesh. Australasian Accounting Business and Finance Journal, 4(1):76-95.

RECHNER, P.L. \& DALTON, D.R. 1986. Board composition and shareholders wealth: An empirical assessment. International Journal of Management, 3(2):86-92.

ROSENSTEIN, S. \& WYATT, J. 1994. Shareholder wealth effects when an officer of one corporation joins the board of directors of another. Managerial and Decision Economics, 15:317-327.

ROSSOUW, G.J. 2005. Business ethics and corporate governance in Africa. Business \& Society, 44(1): 94-106.

RYAN, B., SCAPENS, R. \& THEOBALD, M. 2002. Research method and methodology in finance and accounting. ( $2^{\text {nd }}$ ed.) London: Thomson.

SAHIN, K., BASFIRINCI, C.S. \& OZSALIH, A. 2011. The impact of board composition on corporate financial and social responsibility performance: Evidence from public-listed companies in Turkey. African Journal of Business Management, 5(7):2959-2978.

SANDA, A., GARBA, T. \& MIKAILU, A.S. 2011. Board independence and firm financial performance: Evidence from Nigeria. No. RP_213, African Economic Research Consortium, Nairobi, Kenya.

SHEATHER, S.J. 2009. A modern approach to regression with R. Texas: Springer. 
SINGH, J., HOUSE, R. \& TUCKER, D. 1986. Organizational change and organizational mortality. Administrative Science Quarterly, 31:171-193.

SOLOMON, J.F. 2010. Corporate governance and accountability. ( $3^{\text {rd }}$ ed.) West Sussex, UK: John Wiley. VAFAS, N. \& THEODOROU, E. 1998. The relationship between board structure and firm performance in the UK. The British Accounting Review, 30:383-407.

VAN STADEN, C.J. 1998. The usefulness of the value added statement in South Africa. Faculty of Economic and Management Sciences, University of Pretoria, Pretoria.

WEISBACH, M. 1988. Outside directors and CEO turnover, Journal of Financial Economics, 20:431-460. WILLIAMSON, O. 1984. Corporate governance. Yale Law Journal, 93:1197-1229.

WU, Y. 2003. Honey, Calpers shrunk the board! Journal of Corporate Finance, 8:313-336.

YERMACK, D. 1996. Higher market valuation of companies with small board of directors. Journal of Financial Economics, 40(2):185-211.

ZAHRA, S.E. \& PEARCE, J. 1989. Boards of directors and corporate financial performance: A review and integrative model. Journal of Management, 15:291-244. 